\title{
Development of Guided Discovery-based Teaching Material on Real Analysis Course
}

\author{
Suharti ${ }^{*}$, Fitriani Nur, Nuramaliyah Ramadhany, Andi Dian Angriani, A. Sriyanti \\ Department of Mathematics Education, Faculty of Tarbiyah and Teacher Training, Universitas Islam Negeri Alauddin Makassar, \\ Indonesia
}

Received August 12, 2020; Revised November 9, 2020; Accepted November 19, 2020

\begin{abstract}
Cite This Paper in the following Citation Styles
(a): [1] Suharti, Fitriani Nur, Nuramaliyah Ramadhany, Andi Dian Angriani, A. Sriyanti, "Development of Guided Discovery-based Teaching Material on Real Analysis Course," Mathematics and Statistics, Vol. 8, No. 12A, pp. 7567 7571, 2020. DOI: 10.13189/ujer.2020.082542.
\end{abstract}

(b): Suharti, Fitriani Nur, Nuramaliyah Ramadhany, Andi Dian Angriani, A. Sriyanti (2020). Development of Guided Discovery-based Teaching Material on Real Analysis Course. Mathematics and Statistics, 8(12A), 7567 - 7571. DOI: 10.13189/ujer.2020.082542.

Copyright $\odot 2020$ by authors, all rights reserved. Authors agree that this article remains permanently open access under the terms of the Creative Commons Attribution License 4.0 International License

\begin{abstract}
This study aims to find out the process and quality of the development of guided discovery-based teaching material on real analysis course which meets valid, practical, and effective criteria. The type of research is Research and Development with reference to ADDIE instructional development model. The product developed is the form of teaching material, which is a guided discovery-based teaching material in real analysis courses. The subjects of this study were students of the Department of Mathematics Education UIN Alauddin Makassar class of 2017. The instruments used were expert validation sheets, student and lecturer response questionnaires, student activity observation sheets, observation sheets of teaching material implementation, and learning achievement tests. Referring to the results of the research conducted, it was found that the process of developing teaching materials in this study using the ADDIE instructional development model included five stages, namely analysis, design, development, implementation, and evaluation. The development of guided discovery-based teaching material on real analysis course of students of the Department of Mathematics Education UIN Alauddin Makassar has met the criteria of validity, practicality, and effectiveness.
\end{abstract}

Keywords Teaching Material, Guided Discovery, Real Analysis

\section{Introduction}

Education is a universal activity in human life. In any part of the world, if there is a community there is also education [1]. Education is more emphasized in the process. The education process is an activity carried out by an educator in a directed manner which aims to determine the quality of the achievement of educational goals [2]. Education always helps members of society by providing essential understanding and expertise to become functional individuals [3]. Education plays a big role in the success of national development. Therefore, the government and its competent elements must pay attention to the development and progress of education in Indonesia.

Mathematics can be used as an essential capital in life, mainly used to solve everyday problems [4]. Mathematics is a training lesson for students to develop and improve logical, critical, and creative thinking [5]. Mathematics learning emphasizes on the modern pedagogic dimension namely using a scientific approach [6]. Namely the learning which prioritizes the exact knowledge, right and straight to the target so that the discipline in thinking can be created and train the students to think simple, clear, precise, and fast [7]. Mathematics is also a structured and systematic science. This implies that concepts and principles in mathematics are interrelated with one another [8]. This linkage makes many students have difficulty when learning mathematics. 
The real analysis is a compulsory subject for students majoring in mathematics education that can train students to think structurally and deductive rational, and help improve students' abilities in terms of analysis, logical thinking, and systematic. The real analysis material generally discusses about proof of theorems which really require high analytical thinking. In following the real analysis course, students are also required to always have a good learning readiness which requires high reasoning power and logic. Therefore, most students consider that real analysis is a difficult subject, so it has an impact on the suboptimal learning outcomes of students.

This is consistent with the results of preliminary observations made on students majoring in mathematics education at UIN Alauddin Makassar class of 2016. Submission of material in the learning process was still dominant centered on lecturers, so the students were less active in learning. In addition, the teaching materials available only provide direct evidence of a theorem so that students are not trained to discover the concepts or principles of a material. Based on the interview with one of the students in mathematics education UIN Alauddin Makassar class of 2016 who said that the real analysis course was a subject that is very difficult to understand, especially the concepts and principles of real analysis. It causes the low value of students which can be seen from the test scores of students majoring in mathematics in 2016 for real analysis courses. The results of the test showed that only $63 \%$ of students received a minimum grade of 75 .

One effort which can be conducted to solve these problems is to develop teaching materials. According to the National Center for Competency Based Training in Nur, teaching materials are all forms of material used to assist teachers or instructors in implementing the learning process [9]. These teaching materials can be printed or non-printed [10] which can be used as alternatives in the learning process [11]. In line with this, according to Amri \& Ahmadi in Purwanto \& Rizki, teaching materials consist of: (1) visuals, which are printed, such as handouts, books, teaching materials, student worksheets, brochures, leaflets, wallcharts, photos/ images, and non-printed, such as model/ maket images, 2) audio such as cassettes, radios, vinyl records, and compact audio disks, 3) audiovisuals, such as compact disks and films, 4) interactive teaching materials such as CAI (Computer Assisted Instruction) and compact disk [12]. It is expected that these teaching materials can help educators in carrying out teaching and learning activities in the classroom.

\section{Methods}

This research is a research and development $(\mathrm{R} \& \mathrm{D})$ by adopting the ADDIE instructional development model. According to Mulyatiningsih, the steps at each stage of
ADDIE instructional development are as follows: (1) Analysis phase, namely analyzing the need to develop new teaching materials that are initiated by problems in teaching materials which had been applied, for example existing teaching materials are no longer relevant to the needs of the target, learning environment, technology, and characteristics of students. The researcher also need to analyze the feasibility and requirements for developing new teaching materials. (2) The design stage, namely setting learning objectives, designing scenarios or teaching and learning activities, learning tools, materials, and evaluating tools for learning outcomes. (3) Development stage, namely the realization of product design. In this stage of development, a conceptual framework was realized into a product that is ready to be implemented. (4) Implementation phase, i.e. applying the real situations in the classroom. 5) Evaluation stage, namely revising based on input from users of teaching materials [17].

The test subjects in this study were students of the Department of Mathematics Education UIN Alauddin Makassar class of 2017. The selection of trial subjects was based on student characteristics at the time of initial observation. The instruments used were expert validation sheets, student response questionnaires, lecturer response questionnaires, student activity observation sheets, observation sheets of teaching material implementation, and learning achievement tests.

\section{Result}

The development of teaching materials in this study applied the ADDIE instructional development model through five stages, namely analysis, design, development, implementation, and evaluation.

The analysis phase consists of instructional analysis and student analysis. While the instructional analysis was done by analyzing the subject matter. In this phase the researcher analyzed the material, which was the material sequence of real numbers and function limits in the real analysis course. In the student analysis, the researcher found that students had difficulty in understanding the concepts and principles of the real analysis course and the learning process was still dominantly centered on lecturers so that the students were less active in the learning process.

The design phase consists of compiling module design and design research instruments. The module or teaching material design was compiled from the material side as well as from the media side. In terms of material, modules were developed based on material that has been studied previously in the real analysis course completed with the syntax of the guided discovery model. On the media side, the module was developed with a graphic design which was made interesting and equipped with instructions for 
use and concept maps so that the students had no difficulty in using and understanding the contents of the module. The modules compiled consist of a title, preface, table of contents, concept map, introduction, learning indicators, material description, examples, learning activities, exercises, formative tests, bibliography, and glossary.

At the development stage, modules were arranged with specifications in the form of print media, displayed with layouts in accordance with the design display modules which had been determined at the design stage, and were arranged in accordance with the sequence of learning steps based on guided discovery. One of them was the activity of proving a theorem using the syntax of guided discovery. In addition, at the course design (SAP) development and instruments in the form of student response questionnaire, lecturer response questionnaire, student activity observation sheet, observation sheet of teaching material implementation, and learning achievement test were conducted. After the development of instructional materials had been completed, these teaching materials were validated by the material expert validator and the media expert, the teaching materials were declared worth testing with revisions. In terms of suggestions for improvement from the validator, the researcher made a revision before being trialled. The minimum average of the total aspects is 3.5 which is in the sufficient category to fulfill valid criteria [18]. The results of validation by experts can be seen in the following table 1.

Table 1. Summary of Validation Results

\begin{tabular}{|c|c|c|c|}
\hline No. & Source & Mean Score & Criteria \\
\hline 1 & Module & 4,3 & Valid \\
\hline 2 & Course Design (SAP) & 4,4 & Valid \\
\hline 3 & $\begin{array}{l}\text { Student response } \\
\text { questionnaire }\end{array}$ & 4,4 & Valid \\
\hline 4 & $\begin{array}{c}\text { Lecturer response } \\
\text { questionnaire }\end{array}$ & 4,4 & Valid \\
\hline 5 & $\begin{array}{c}\text { Student activity } \\
\text { observation sheet }\end{array}$ & 4,5 & Valid \\
\hline 6 & $\begin{array}{c}\text { Observation sheet of } \\
\text { teaching material } \\
\text { implementation }\end{array}$ & 4,3 & Valid \\
\hline 7 & $\begin{array}{c}\text { Learning achievement } \\
\text { test }\end{array}$ & 4,4 & Valid \\
\hline \multicolumn{2}{|c|}{$\begin{array}{l}\text { The Total Mean Scores of } \\
\text { Instrument Validity }\end{array}$} & 4,4 & Valid \\
\hline
\end{tabular}

The implementation phase is carried out to measure the practicality and effectiveness of the teaching materials that had been developed. Practicality of teaching materials is the convenience felt by users of teaching materials. The set criteria are more than $50 \%$ of the respondents who give positive responses toward the minimum $70 \%$ of the aspects asked. Then, the average of the observation is 1.5 . Thus, based on the results this module fulfills the practical criteria [19]. The practicality of teaching materials can be seen from the average percentage of student responses from all aspects is $89.45 \%$ and the average lecturer response from all aspects is $100 \%$. The sheet implementation of teaching materials is one of the practical support for teaching materials including syntax components, social interaction, and the principle of reaction. All three components were carried out entirely. This shows that guided discovery-based teaching materials in real analytical subjects were practical to use. The results of practical teaching materials can be seen in table 2 below.

Table 2. The Results of Practical Teaching Materials

\begin{tabular}{|c|c|c|c|}
\hline No. & The assessment sheet & $\begin{array}{c}\text { Mean } \\
\text { Score }\end{array}$ & Category \\
\hline 1 & $\begin{array}{c}\text { The students response } \\
\text { questionnaires }\end{array}$ & $89,45 \%$ & Practical \\
\hline 2 & $\begin{array}{c}\text { The lecturers response } \\
\text { questionnaires }\end{array}$ & $100 \%$ & Practical \\
\hline 3 & $\begin{array}{c}\text { Observation sheet of teaching } \\
\text { material implementation }\end{array}$ & 1,99 & Practical \\
\hline
\end{tabular}

Furthermore, the percentage of the students' activities is $\geq 60$ which is categorized as effective [20], and the learning outcome test will be considered effective if there is at least $85 \%$ of the respondents pass it [21].The effectiveness of teaching materials can be seen from the results of learning outcomes tests which show that the percentage of the students' mastery learning is $86.11 \%$ and the percentage of completeness is $13.89 \%$. In addition to learning achievement tests, student activities were also observed which consisted of 7 categories of observations. The average results of observations of student activity is $88.28 \%$ with a very good category. It can be inferred that the guided discovery-based module in the real analytical course is effective to use, it can be seen in table 3 .

Table 3. Teaching Material Effectiveness Test Result

\begin{tabular}{|c|c|c|c|}
\hline No. & The assessment sheet & Mean Score & Category \\
\hline 1 & Learning Outcomes Test & $86,11 \%$ & Effective \\
\hline 2 & $\begin{array}{c}\text { Student activity } \\
\text { observation sheet) }\end{array}$ & $88,28 \%$ & Effective \\
\hline
\end{tabular}

The last step is evaluation. At this stage an assessment of guided discovery-based instructional materials was conducted on the real analysis courses that had been produced. At this stage the teaching material was revised if needed regarding to criticism and input from users of teaching materials.

This study is relevant to the research conducted by Suryanto, Zulela, Noornia, \& Iasha which explains that in terms of learning outcomes and student questionnaire responses, the guided discovery-based module is effective to use [22]. Likewise, research conducted by Wijayanti explained that based on teacher assessment, student assessment, and observations of learning outcomes, the guided discovery-based learning device was declared practical and effective to apply [23]. 
The guided discovery-based teaching material on real analysis course contributes easiness for the lecturers to conducting the course. Moreover, the teaching material can enhance and enrich the students' knowledge so that it can improve their learning process and progress especially in the real analysis course.

\section{Conclusion}

The conclusion obtained from this study is the process of developing teaching materials using the ADDIE development model consisted of five stages, including analyses, namely conducting instructional analysis and student analysis; design, namely designing teaching materials, Course Design (SAP), and learning achievement tests; development, namely products and instruments that have been designed and then developed into a whole teaching material which is ready to be validated; implementation, i.e. teaching materials that have been valid are then applied to the test subjects to obtain practicality and effectiveness data; and evaluation which is to make revisions based on input from users of teaching materials. Referring to the results of the real analysis trial of guided discovery-based teaching materials, the valid, practical and effective teaching materials are obtained.

\section{REFERENCES}

[1] M. N. Purwanto, Ilmu Pedidikan Teoritis dan Praktis. Bandung: PT Remaja Rosdakarya, 2000.

[2] D. Nugraheni, "Analisis Kesulitan Belajar Mahasiswa pada Mata Kuliah Mekanika,” EduSains J. Pendidik. Sains Mat., vol. 5, no. 1, pp. 23-32, 2017.

[3] T. F. Peniero and M. Toshihiko, "Science Teaching and Learning in Japan and the Philippines: A Comparative Study," Univers. J. Educ. Res., vol. 8, no. 4, pp. 1237-1245, 2020. DOI: 10.13189/ujer.2020.080414.

[4] J. Supriyanto, Suparman, and Y. Hairun, "Design of Worksheets for RME Model to Improve Mathematical Communication," Univers. J. Educ. Res., vol. 8, no. 4, pp. 1363-1371, 2020. DOI: 10.13189/ujer.2020.080429.

[5] Nursalam, A. D. Angriani, Darmawati, Baharuddin, and Aminuddin, "Developing Test Instruments for Measurement of Students' High-Order Thinking Skill on Mathematics in Junior High School in Makassar," in Journal of Physics: Conference Series, 2018, pp. 1-5.

[6] Suharti, N. K. Latuconsina, Tasril, A. Sriyanti, and A. Halimah, "The Effect of the Realistic Mathematical Approach Towards the Result of Learning Mathematics Reviewed from the Ability of Numerical Students," in Journal of Physics: Conference Series, 2018, pp. 1-7.

[7] T. Tayeb, A. D. Angriani, S. R. Humaerah, S. Sulasteri, and
M. R. Rasyid, "The Students' Errors in Answering Geometric Tests with Newman Procedures," in Journal of Physics: Conference Series, 2018, pp. 1-7.

[8] M. D. Siagian, "Kemampuan Koneksi Matematik dalam Pembelajaran Matematika," MES (Journal Math. Educ. Sci., vol. 2, no. 1, pp. 58-67, 2016.

[9] F. Nur, "Pengembangan Bahan Ajar Matematika Kelas VII SMP Berdasarkan Model Pembelajaran Kolb-Knisley Berbantuan Geogebra sebagai Upaya Meningkatkan Higher-Order Thinking Skill dan Apresiasi Siswa terhadap Matematika," MaPan J. Mat. dan Pembelajaran, vol. 5, no. 1, pp. 96-109, 2017.

[10] N. Sari, M. S. Sumantri, and I. G. Bachtiar, "The Development of Science Teaching Materials Based on STEM to Increase Science Literacy Ability of Elementary School Students," Int. J. Adv. Sci. Res. Eng., vol. 4, no. 7, pp. $161-169,2018$.

[11] J. A. Opara and N. S. Oguzor, "Instructional Technologies and School Curriculum in Nigeria: Innovations and Challenges," Perspect. Innov. Econ. Bus., vol. 7, no. 1, pp. 66-71, 2011.

[12] Y. Purwanto and S. Rizki, "Pengembangan Bahan Ajar Berbasis Kontekstual pada Materi Himpunan Berbantu Video Pembelajaran," AKSIOMA J. Progr. Stud. Pendidik. Mat., vol. 4, no. 1, pp. 67-77, Jun. 2015.

[13] L. A. Effendi, "Pembelajaran Matematika dengan Metode Penemuan Terbimbing untuk Meningkatkan Kemampuan Representasi dan Pemecahan Masalah Matematis Siswa SMP," J. Penelit. Pendidik., vol. 13, no. 2, pp. 1-10, 2012.

[14] I. Zulkarnain and N. A. Sari, "Model Penemuan Terbimbing dengan Teknik Mind Mapping untuk Meningkatkan Kemampuan Pemahaman Konsep Matematis Siswa SMP," EDU-MAT J. Pendidik. Mat., vol. 2, no. 3, pp. 240-249, May 2014.

[15] L. D. Haeruman, W. Rahayu, and L. Ambarwati, "Pengaruh Model Discovery Learning terhadap Kemampuan Berpikir Kritis Dan Hasil Belajar Siswa," JPPM, vol. 10, no. 2, pp. 157-168, 2017.

[16] A. Bahri, N. Musmuliadi, and M. Palennari, "Pembelajaran Efektif: Meningkatkan Hasil Belajar Peserta Didik melalui Penggunaan Lembar Kerja Berbasis Penemuan Terbimbing,' J. Penelit. Pendidik. Insa., vol. 20, no. 2, pp. 73-79, Jan. 2017.

[17] E. Mulyatiningsih, Riset Terapan Bidang Pendidikan dan Teknik. Yogyakarta: UNY Press, 2011.

[18] R. N. Afifa, "The Development of Mathematics Learning Instrumen Through Cooperative Learning with the Combination of Scientific and Realistic," J. Daya Mat., vol. 5, no. 1, pp. 49-68, 2017.

[19] N. Arsyad, Model Pembelajaran Menumbuhkembangkan Kemampuan Metakognitif. Makassar: Pustaka Refleksi, 2016.

[20] H. Arrasyid, Jufrida, and Darmaji, "Aktivitas dan Hasil Belajar Siswa dengan Menggunakan Model Pembelajaran Problem Based Learning Berbantuan Lembar Kerja Siswa pada Materi Kalor dan Perpindahannya Kelas X SMA PGRI 2 Jambi," J. EduFisika, vol. 2, no. 2, pp. 68-80, 2017. 
[21] S. P. Lestari, "Meningkatkan Hasil Belajar Bahasa Inggris pada Materi Narrative Text melalui Penggunaan Media Audio Visual di Kelas IX 3 SMPN 3 Pasir Penyu TP. 2016/2017," J. Pendidik. Tambusai, vol. 2, no. 6, pp. 16311640, 2018.

[22] Suryanto, Zulela, A. Noornia, and V. Iasha, "Pengembangan Modul Pembelajaran Matematika Berbasis Penemuan
Terbimbing tentang Pengukuran di Kelas IV Sekolah Dasar," JPD J. Pendidik. Dasar, vol. 8, no. 2, pp. 124-134, 2017.

[23] D. Wijayanti, "Pengembangan Perangkat Pembelajaran Statistika dan Peluang dengan Metode Penemuan Terbimbing Berorientasi Kurikulum 2013 untuk Siswa Kelas X," J. Ris. Pendidik. Mat., vol. 3, no. 1, pp. 23-33, 2016 . 